\title{
The Evaluation of the Stability of Donan Cave, Pangandaran, West Java, Based on the Classification of Rock Mass
}

\author{
Ikfi Maasyi Hanif, I Gde Budi Indrawan*
}

Department of Geological Engineering, Faculty of Engineering, Universitas Gadjah Mada, Yogyakarta, Indonesia

Submitted: Juny 28 ${ }^{\text {th }}$ 2019; Revised: Juny 11 ${ }^{\text {th }} 2021$; Accepted: December $8^{\text {th }} 2021$

\begin{tabular}{|c|c|}
\hline $\begin{array}{l}\text { Keywords: } \\
\text { Donan cave } \\
\text { Q system } \\
\text { Rock mass } \\
\text { classification } \\
\text { Rock mass } \\
\text { quality }\end{array}$ & $\begin{array}{l}\text { Abstract Assessment of rock mass quality was conducted to estimate the } \\
\text { stability of Donan Cave. This research involved geological mapping, cave } \\
\text { geometry mapping, rock mass quality zoning by scanline survey based on the } \\
\text { Q-system rock mass classification, and cave stability estimation based on the } \\
\text { rock mass quality, ratio of cave roof thickness to width, and load. The research } \\
\text { results indicate that Donan Cave is composed of limestone of the Kalipucang } \\
\text { Formation. Several faults are located in the vicinity of Donan Cave. Donan Cave } \\
\text { is dominated by good to very good quality rock masses and is estimated to be } \\
\text { stable in a relatively long period of time. However, rock fall hazard due to } \\
\text { dynamic load at several zones, which have relatively thin and poor-quality rock } \\
\text { masses has to be anticipated. }\end{array}$ \\
\hline
\end{tabular}

\section{INTRODUCTION}

The research site is Donan Cave in Tunggilis Village, Kalipucang, Pangandaran Regency (Figure 1). Donan Cave was a popular tourist attraction in the 1970s. The conversion of half of the cave into a swallow's nest and the collapse of the rock walls in 2005 are thought to be the reasons for the downturn of tourists visiting Donan Cave, and making this cave no longer regarded as a viable tourist attraction.

In December 2016, Donan Cave was reopened by the community, supported by the Village Government, by completely restoring its function as a tourist attraction. Furthermore, the community expects that the government would be involved in the development of the Donan Cave natural tourist attraction. However, the history of rock collapse of the cave walls caused by limestone mining surrounding the cave using the blasting method has gained attention. It is necessary to conduct a research to estimate rock mass stability that construct the cave for the safety of the tourists visiting Donan Cave.

The stability of rock mass can be estimated through various methods, namely rock mass classification (González de Vallejo \& Ferrer, 2011). Rock mass classification is the foundation of empirical design approaches and is widely used in rock engineering. In many construction projects, the rock mass classification approach is often the only practical basis for designing complex underground structures (Singh dan Goel, 2011). The Q system (Barton et al., 1974) is one of the rock mass classifications that is often used in assessing the stability of rock masses that construct tunnels and underground spaces. The $\mathrm{Q}$ value can be obtained through scanline survey on rock mass outcrops. The $\mathrm{Q}$ value indicates the quality of rock mass. Qualitatively, the quality of rock mass indicates the stability of rock mass.

The number of researches on the stability of natural caves constructed by carbonate rocks using a rock mass classification system is limited. The stability of natural caves constructed by carbonate rocks is difficult to estimate (Hatzor et al., 2002). Abdullatif (2010) researched the geomechanical characteristics and quality of carbonate rock mass at Dammam dome using the Q and RMR classification (Bieniawski, 1989). Lai et al. (2018) conducted a research on the stability of limestone caves in Malaysia using the method proposed by Waltham \& Fookes (2003). Waltham \& Fookes (2003) stated that naturally formed caves are often more stable than excavated caves. The classification of rock

ISSN 2460-9447 (print), ISSN 2541-5883 (online)

${ }^{*}$ Corresponding author : I Gde Budi Indrawan

Department of Geological Engineering, Faculty of Engineering, Universitas Gadjah Mada, Grafika Street No.2 Kampus UGM, Yogyakarta 55281, Indonesia

Email: igbindrawan@ugm.ac.id 
mass systems Q and RMR, which are often used to assess the stability of excavated caves, will result in predictions of natural cave stability that are lower than the actual level of stability.

Research related to the stability of rock mass that construct Donan Cave has never been done before. Research related to the geological condition in Pangandaran area, including the Donan Cave area, and its surroundings had been conducted previously by van Bemmelen (1949) and Simandjuntak \& Surono (1992). Both research are regional in scope and showed that Donan Cave area and its surroundings are constructed of limestone. The detailed research in Donan Cave area was conducted by Median (2019). Median's (2019) research was conducted concurrently with this study, but it aims to identify the position, orientation, and continuity of this cave using the geoelectrical geophysical survey method.

This paper presents the results of mass rock quality to estimate the stability of limestone masses that construct Donan Cave according to the Q system rock mass classification. This research was conducted at the request of the Tunggilis Village Government and with the assistance of Donan Cave Tourism Management Community (Komunitas Pengelola Pariwisata (KOMPEPAR) Gua Donan) as a form of community service.

\section{METHOD}

The quality of rock mass was determined based on the Q system classification. Analysis of rock mass quality was done by collecting data obtained from field investigations. The field investigations include geological mapping of Tunggilis Village area of $3 \times 6$ $\mathrm{km}^{2}$, lateral (top view) and vertical (side view) cave mapping, as well as rock mass quality mapping. Geological mapping was conducted by examining the distribution of rocks and geological structures in the research area. The map was made with a scale of $1: 25,000$.

The mapping of the cave's geometry began with reconnaissance activities assisted by the residents around the cave (Figure 1). The mapping of the distance, azimuth, and slope between stations, aisle width, roof height, and sketches preparation were done by referring to the system established by British Cave Research Association (BCRA) and using 3B (Prasetyo, 2015).

The mapping of rock mass quality was conducted by investigating the parameters for rock mass classification according to the $\mathrm{Q}$ system, including discontinuity frequency $(\lambda)$, number of joint sets $\left(J_{n}\right)$, joint roughness $\left(\mathrm{J}_{\mathrm{r}}\right)$, joint alteration $\left(\mathrm{J}_{\mathrm{a}}\right)$, joint water reduction factor $\left(\mathrm{J}_{\mathrm{w}}\right)$, and stress reduction factor $(\mathrm{SRF})$ (Barton et al., 1974). These parameters were collected through mapping using a scanline method in which the rock mass was considered to be of equal quality on both sides of the cave. In this method, the data collection for rock mass classification was done with a distance of 2 meters between stations and a 247 meters path along the side of the cave so that 137 STA were obtained, with details of 126 STA on the main route of the cave and 11 STA on the branch route. The analysis of rock mass classification was conducted to identify rock mass quality and Donan Cave stability based on the Q system score.

A geophysical study using dipole-dipole configuration geoelectric method was also conducted simultaneously in this activity by Median (2019) to acquire data on the thickness of the cave roof and the depth of the groundwater table.

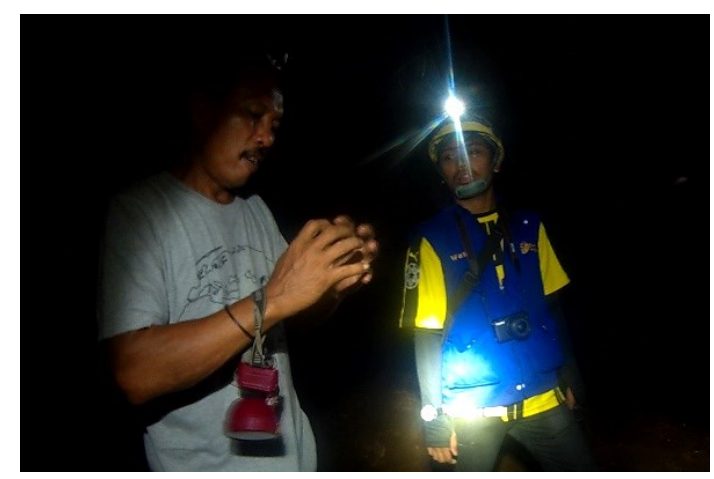

Figure 1. Reconnaissance activity was guided by Mr. Kandar, a local resident who is also the head of KOMPEPAR of Donan Cave, on 17 June 2017

\section{RESULT AND DISCUSSION}

\subsection{Geological Condition}

Physiographically, the research area is included in western Java's Southern Mountain Zone (Figure 2), to be precise, near the easternmost tip of the Karangnunggal sector. This part is the easternmost part of the zone, and it is a relatively low mountain with a height of generally less than 100 meters above sea level with karst topography (van Bemmelen, 1949).

The result of geological mapping shows that Donan Cave and its surroundings consist of limestone, tuffaceous marl, alternating sandstone-siltstone, andesite lava, tuffaceous diamictite, as well as clay, sand, and gravel deposits. According to the regional geological map of Pangandaran (Simandjuntak dan Surono, 1992), the limestones that construct Donan Cave are the part of Kalipucang Formation (Figure 3).

Geological structures such as reverse faults, normal faults, sinistral shear faults, shear joint, and tension joint are found in the mapping area. However, none of these faults intersect the Donan Cave.

\subsection{Cave Geometry}

Cave mapping was done to create a cave map which will be used as a basis for zoning the quality of 


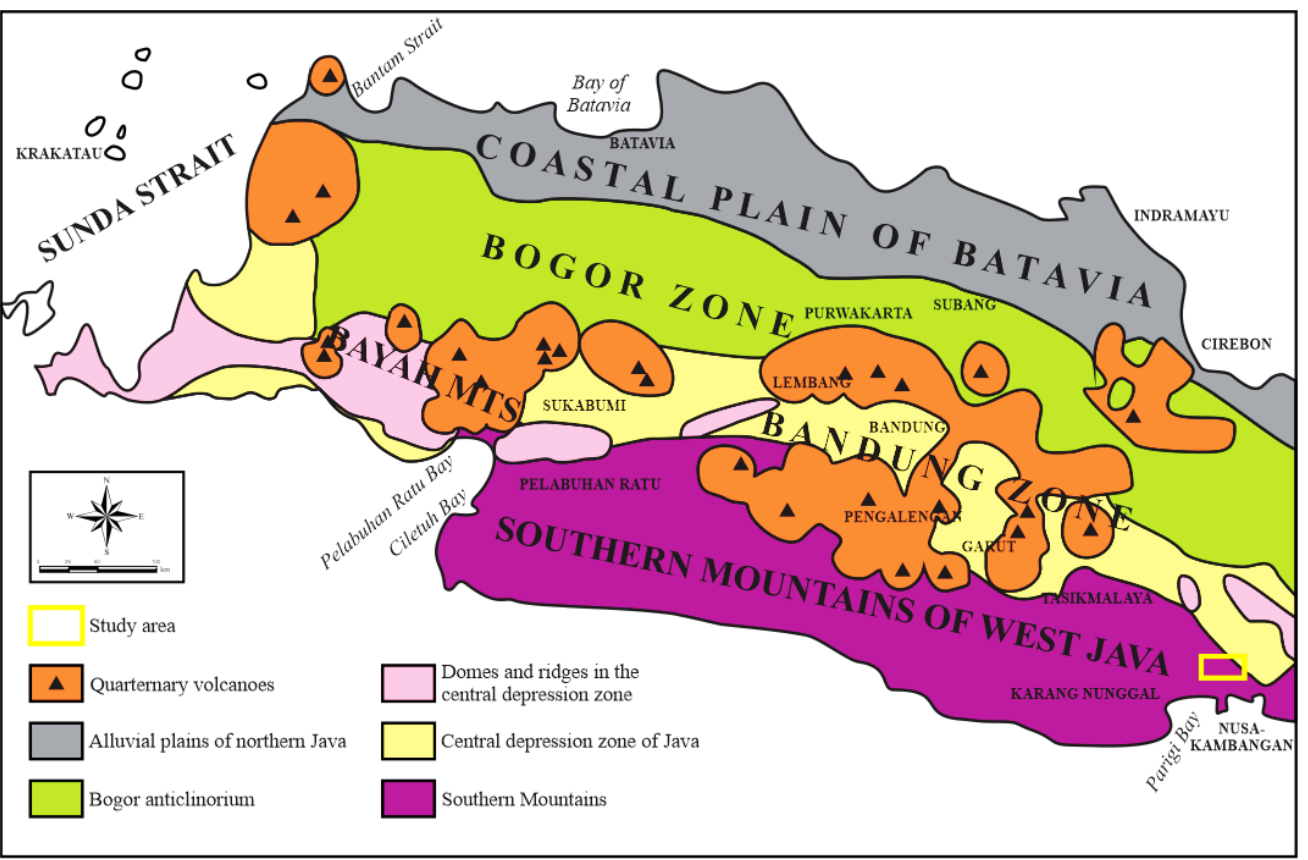

Figure 2. Physiographic map of West Java (van Bemmelen, 1949)

the cave rock mass. In addition, the results of the lateral and vertical map (Figure 4) are also displayed at the cave counter as a guide for the tourists.

The cave has a main west-east axis, two entrances (main and branch), as well as one main and one branch track. The main track is 257 meters long with four chambers and three corridors, while the branch track is 28 meters long and is only a branching aisle from the second chamber.

The cave's main entrance is located at the coordinate 249233, 9157550 and an elevation of 27.7 meters. The coordinates of the cave are only recorded at the main entrance because GPS cannot function in the cave. The cave's lowest point is in the first chamber with an elevation of 25 meters, while its highest point is in the last chamber with an elevation of 32.1 meters, which is also the largest chamber with a cave roof height of 13.2 meters.

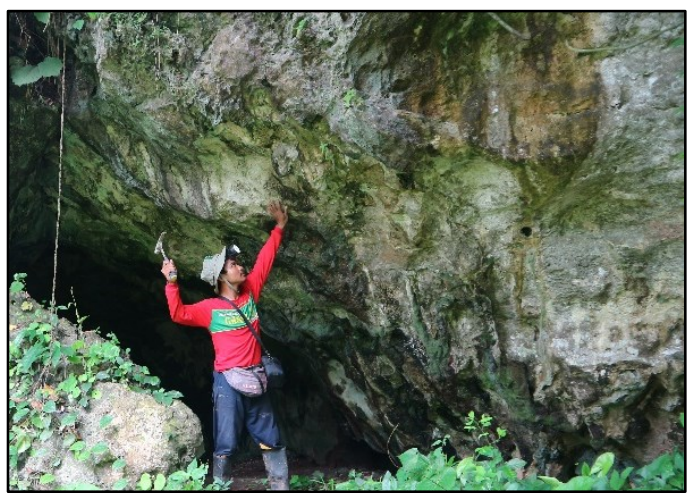

Figure 3. Limestones unit at the door of the Donan Cave's branch (Hanif, 2019)

\subsection{Rock Mass Quality Zone}

The rock mass quality in each zone along the Donan Cave is shown in Figure 5. The rock mass quality zoning in Figure 5 is in a straight line because the investigation of rock mass quality was conducted using the scanline method horizontally within a span of 2 meters, and the rock mass quality was presumed to be the same vertically. Figure 5 shows that Donan Cave is dominantly constructed of rock mass that are good to very good in quality. Poor quality rock mass can only be found in the starting zone of Chamber 2 and end zone of Chamber 3.

Geophysical data processed from Median's (2019) research shows that the groundwater level is below the cave and the depth of the groundwater level is relatively following the elevation of the ground surface above the cave. Field observations also reveal no groundwater in the cave, even though puddles are seen in several basins in Chamber 3 and 4 (Figure 6).

\subsection{Cave Stability}

The results of the research by Waltham and Fookes' (2003) show that karst limestones generally have moderate quality. Natural caves composed of karst limestones are generally stable during the construction period where the thickness of the cave roof rock is more than $70 \%$ of the cave's width, with construction loads of up to $2 \mathrm{MPa}$ on the cave roof. The lateral and vertical sections of the cave in Figure 5 show that the roof rock of Donan Cave's thickness is more than $70 \%$ of the cave width. The load on the roof rock of Donan Cave is less than $2 \mathrm{MPa}$ because there is no construction on top of Donan Cave. Considering the stability parameters of natural caves developed by Waltham and Fookes (2003), namely the quality of rock mass, the thickness of cave roof, and load on cave roof, Donan Cave is estimated to be stable for a relatively long period of time. 


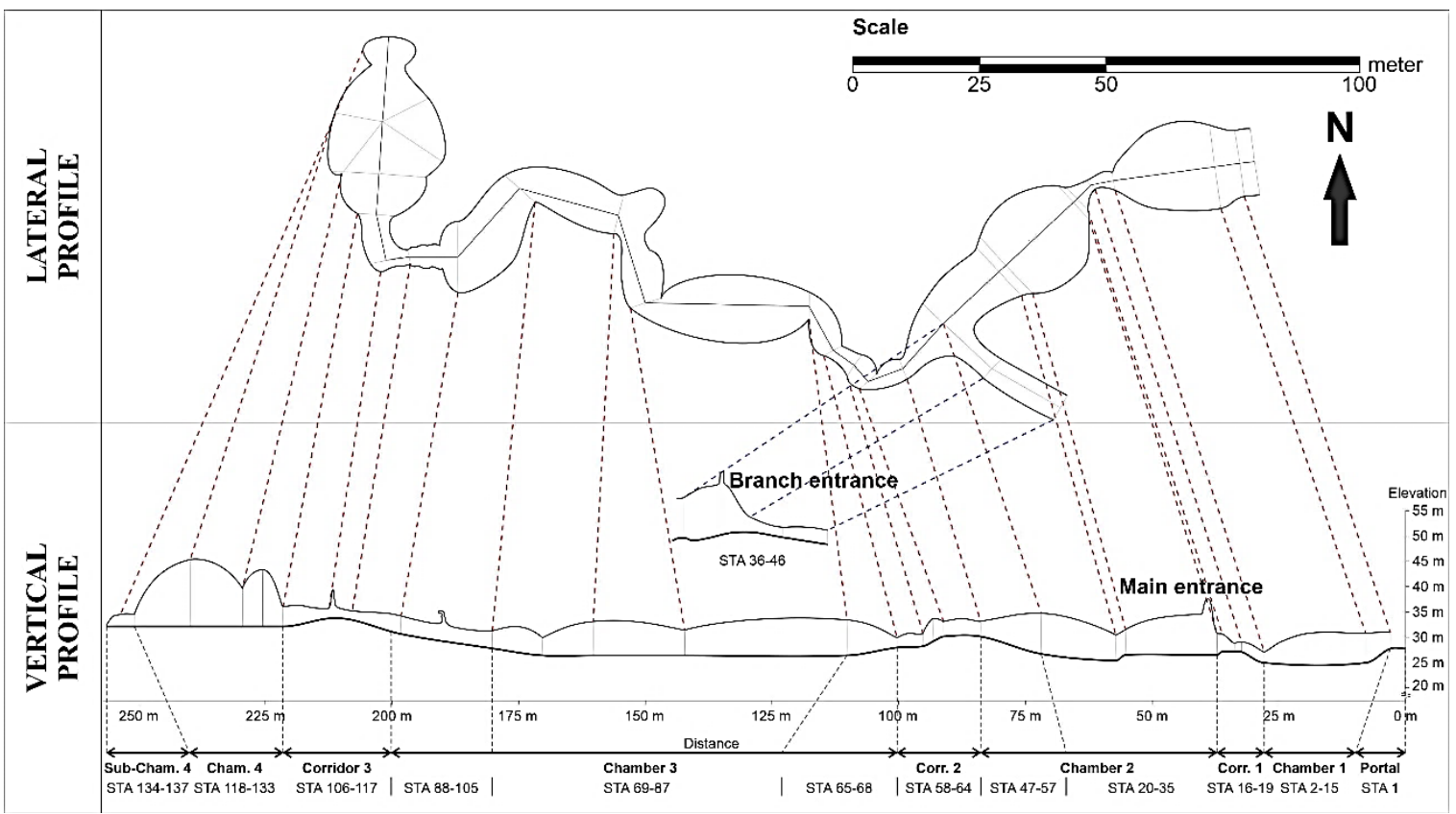

Figure 4. The underground shots map of Donan Cave that includes lateral and vertical sections of the cave (Hanif, 2019)

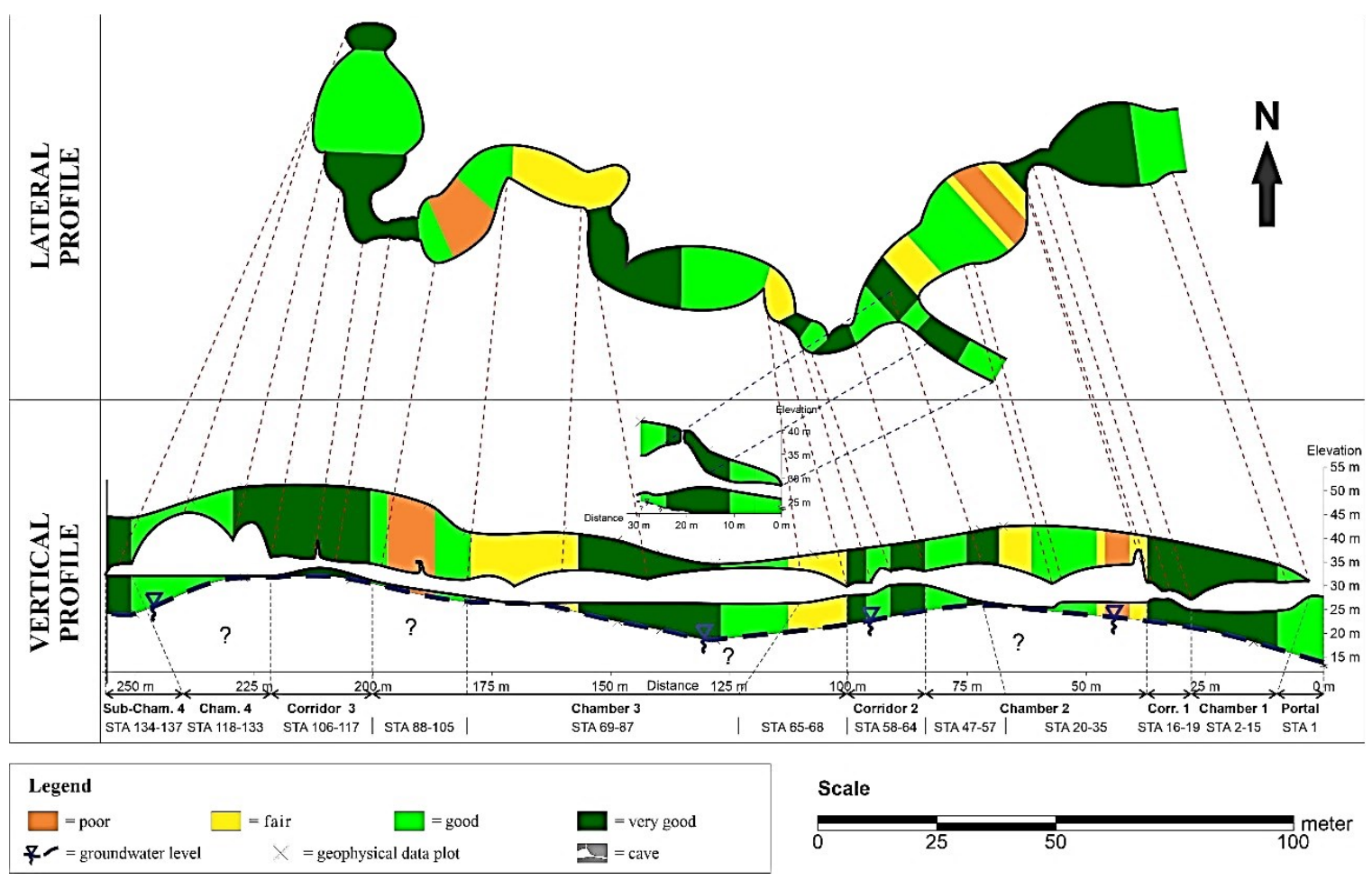

Figure 5. The map of Donan Cave's rock mass quality (Hanif, 2019)

Although Donan Cave is relatively stable, the zones in Chamber 2 (approximately 40 meters from the portal), Chamber 3 (approximately 125 meters from the portal), and Chamber 4 (approximately 225 to 250 meters from the portal) require attention toward hazard rock fall due to poor rock mass quality and relatively thin roof rock. The estimation of cave stability with the method proposed by Waltham and Fookes (2003) only considers static loads. The collapse of Chamber 2's rock walls in 2005 due to vibrations caused by the limestones mining that used blasting method near Donan Cave proves that the stability of Donan Cave, particularly in Chamber 2, 3, and 4, can be impaired by dynamic loads.

Further studies to determine the stability of roof rock of Donan Cave in the long term through field measurements of the bearing capacity of the roof rock of Donan Cave are recommended, particularly in the zones with poor rock mass quality and relatively thin roof rock. In addition, studies on the stability of Donan Cave against dynamic loads, such as vibration loads caused by earthquakes and explosions during the limestone mining process, is also recommended. 


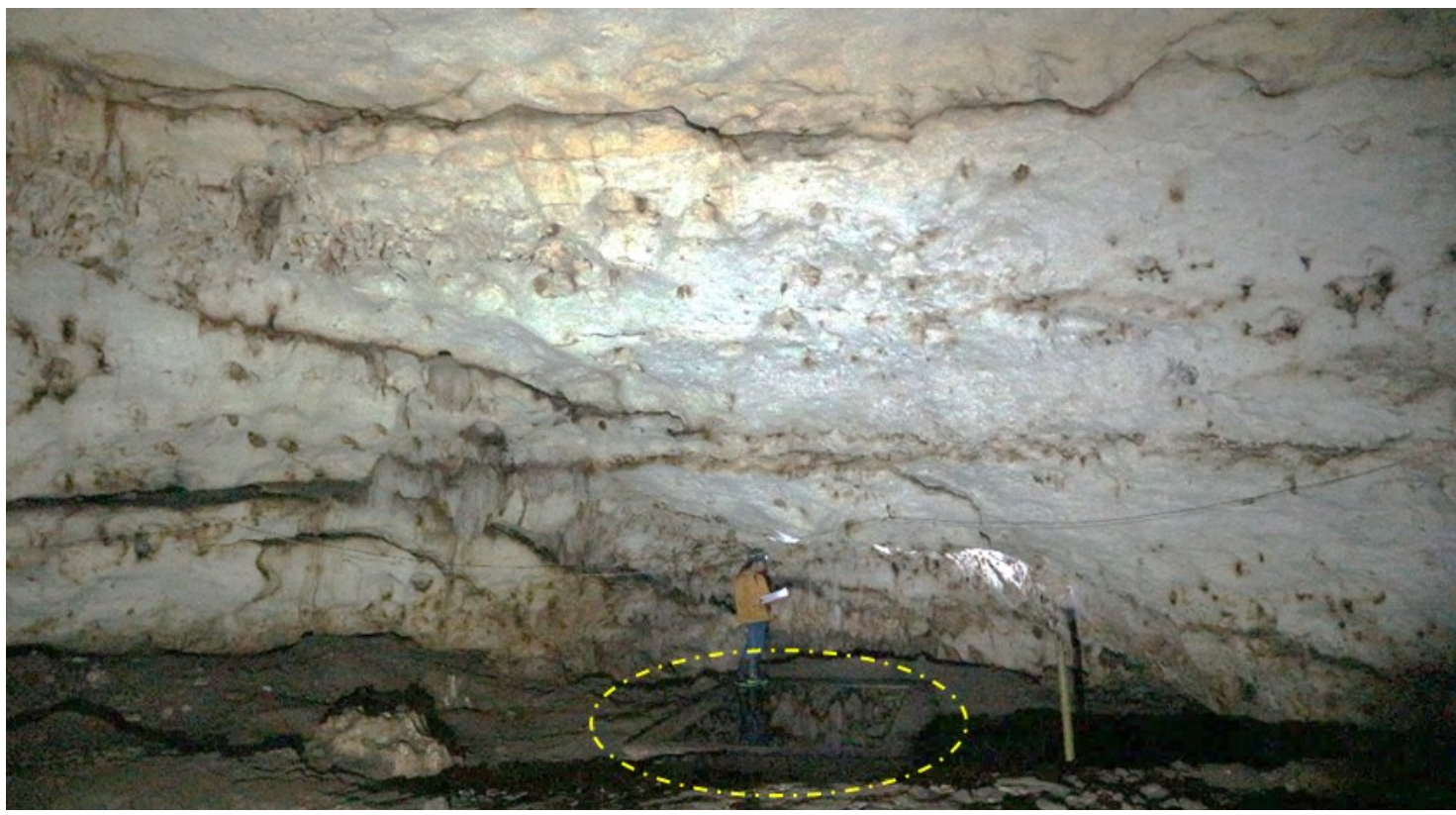

Figure 6. Basin filled with water (marked by the yellow circle) in Chamber 3 (Hanif, 2019)

\section{CONCLUSION}

This research includes geological mapping, cave geometry mapping, rock mass quality zoning through scanline surveys based on the Q system rock mass classification, and cave stability estimation based on rock mass quality, comparison of roof rock thickness and cave width, and load. Donan Cave is entirely constructed of limestone from the Kalipucang Formation. The reverse faults, normal faults, and sinistral shear faults are geological structures in the area surrounding Donan Cave and none of them intersect the cave. The cave features a main west-east axis, two entrances (main and branch), as well as one main and one branch passage. Donan Cave is predominantly constructed of good to very good quality rock masses. Poor quality rock mass is only found in Chamber 2's starting zone and Chamber 3's end zone. Based on the analysis using the approach proposed by Waltham and Fookes (2003), Donan Cave is estimated to be in stable condition for a relatively long time. Several zones in Chamber 2, 3, and 4 require attention to the hazard of rock collapsing due to dynamic loads since the rock mass quality is poor and the roof rock is relatively thin. The local community is expected to actively participate in maintaining the cave stability, such as examining development new cracks, particularly on the cave roof, and supervising mining activity in the surrounding area.

\section{ACKNOWLEDGMENT}

The authors would like to thank Tunggilis Village Government and Donan Cave Tourism Management Community for the permission to conduct this study. The authors would also like to thank Faculty of Enginering, Universitas Gadjah Mada, for the financial support. The assistance of Mr. Kandar of the
KOMPEPAR Donan Cave in conducting site reconnaissance is gratefully acknowledged.

\section{REFERENCES}

Abdullatif, O. (2010). Geomechanical properties and rock mass quality of the carbonate Rus formation, Dammam dome, Saudi Arabia. Arabian Journal for Science and Engineering, 35(2), 173.

Barton, N., Lien, R., \& Lunde, J. (1974). Engineering classification of rock masses for the design of tunnel support. Rock mechanics, 6(4), 189-236. https://doi.org/10.1007/BF01239496

Bieniawski, Z. T. (1989). Engineering rock mass classifications: a complete manual for engineers and geologists in mining, civil, and petroleum engineering. John Wiley \& Sons. https://www.wiley.com/enie/Engineering+Rock+Mass+Classifications: + A + Complete + Manual + for + Engineers + and + Geolo gists+in+Mining, +Civil,+and+Petroleum+Engin eering-p-9780471601722

González de Vallejo, L., \& Ferrer, M. (2011). Geological engineering. CRC Press. https://www.taylorfrancis.com/books/mono/10. 1201/b11745/geological-engineering-luisgonzalez-de-vallejo

Hanif, I. M. (2019). Evaluasi Kestabilan Gua Donan, Pangandaran, Jawa Barat, Berdasarkan Metode Klasifikasi Massa Batuan System Q, RMR, Dan GSI [skripsi sarjana, tidak dipublikasikan]. Universitas Gadjah Mada.

Hatzor, Y.H., Talesnick, M. \& Tsesarsky, M. (2002). Continuum and discontinuum stability analysis of the bell-shaped caverns at Bet Guvrin, Israel. International Journal of Rock Mechanics \& Mining Sciences, 39(7), 867-886. https://doi.org/10.1016/S1365-1609(02)00071-0

Lai, G.T., Mang, W.J., Rafek, A.G., Serasa, A.S., Mazlan, N.A., Razib, A.M.M., Hussin, A., Ern, L.K. \& Mohamed, T.R. (2018). Stability 
Assessment of Limestone Cave: Batu Caves, Selangor, Malaysia. Sains Malaysiana, 47(1), 59-66. https://doi.org/10.17576/JSM-20184701-07

Median, I. (2019). Analisis Data Metode Geolistrik 2-D Konfigurasi Dipole-Dipole Untuk Pemetaan Gua Donan Di Desa Tunggilis, Pangandaran, Jawa Barat [skripsi sarjana, tidak dipublikasikan]. Universitas Gadjah Mada.

Prasetyo, A. G. (2015). Diktat Speleologi (Untuk Kalangan Sendiri). Acintyacunyata Speleological Club.

Singh, B., and Goel, R. K. (2011). Engineering Rock Mass Classification: Tunnelling, Foundations and Landslides: Oxford, Elsevier. https:/www.elsevier.com/books/engineeringrock-mass-classification/goel/978-0-12-3858788

Simandjuntak, T. O. \& Surono, B. J. (1992). Peta Geologi Lembar Pangandaran, Jawa, Skala 1:100.000. Pusat Penelitian dan Pengembangan Geologi.

van Bemmelen, R.W. (1949). The Geology of Indonesia. Government Printing Office.

Waltham, A. C. dan Fookes, P. G. (2003). Engineering classification of karst ground conditions. Quarterly Journal of Engineering Geology and Hydrogeology, 36(2), 101-118. https://doi.org/10.1144/1470-9236/2002-33 